\title{
Treatment of nature by romantic poets
}

\author{
Nasser ud-din sofi \\ Baba Ghulam Shah Badshah University Rajouri.
}

\begin{abstract}
The poetry of the English Romantic Period contains many descriptions and ideas of nature. All these authors discuss in varying degrees, the role of nature in acquiring meaningful insight into the human condition. These writers all make appeal to nature as if it some kind of living entity calls made for nature to rescue the struggling and carry his ideas to the world. Romantic poets love nature and celebrate in its various dimensions. They wrote about the beauty of green meadows, thick forests, thin flowers, high hill, river banks, rural scenes, wild wind, fresh air, sun rises and sets etc. Almost all the romantic poets touched every scene of natural beauty. This paper tries to focus few works of romantic poets like Keats, Shelley, William Words Worth and role of nature.
\end{abstract}

Key words: evoke, carefree, bestow, calm, carefree, nuance, muses.

\section{INTRODUCTION}

The poetry of the English Romantic period contains many descriptions and ideas of nature. All these authors discuss in varying degrees, the role of nature in acquiring meaningful insight into human condition. These writers all make appeals to nature as if it some kind of living entity calls made for nature rescue the struggling and carrying his ideas to the world. Romantic poets love nature and celebrate in its various dimensions. They wrote about the beauty of green meadows, thick forests, thin flowers, high hills, river banks, rural scenes, wild wind, fresh air, sun rises and sets etc Almost every romantic poets touched every scene of natural beauty. The romantics poets substituted love, emotions, imagination, beauty. They viewed several perspectives of nature and its greatness. One writer stated in his introduction to a romantic anthology: the variety of this catalogue implies completeness; surely not phase or feature of the outer natural world is without its appropriate counterpart in the inner world of human personality. Nature then can be all things to all men. nature has answer for all unanswered questions of mankind. They tried to heal sorrows of human beings by writing their verses about nature. Thus romantic poets believe that nature is a source of inspiration. They use simple language and personified nature as God, man etc. This paper focuses on how romantic poets have treated nature and how nature is best guide for happy life.

\section{KEATS:}

Keats is one of the greatest lover and admirer of nature. He expresses the beauty of both real and artistic forms of nature. Everything in nature for him is full of wonder and mystery-the rising sun, the moving cloud, the growing bud and the swimming fish. His love for nature is purely sensuous and he loves the beautiful sights and scenes of nature for their own sake. He believes that "A thing of beauty is a joy for ever'. He looks with child-like delight at the objects of nature. In his poem ode to a Nightingale, he writes:

My heart aches, and a drowsy numbness pains

my sense, as though of hemlock I had drunk

Or emptied some dull opiate to the drains

Keats is astonished to see happiness of the Nightinagle.Before the hearing of song of the bird, he tried many ways of forgetting worries Keats believed he has either been poisoned or is influenced by drug. But Keats felt a tranquil and continual joy in the song of Nightingale and makes him completely happy. It indicates to unite with nature gives eternal happiness for the mankind. Nature woks as a source of generating happiness and is a best guide for human beings to live a happy life.

Another poem of Keats, he praises the artistic beauty of nature. He yearns for eternal beauty: $\mathrm{He}$ portrays the artistic beauty of nature in his poem Ode on a Grecian urn. He addresses the Grecian Urn as"unravished bride of quietness and a foster-child of silence and slow time". He also calls the Grecian urn a "Sylvan historian "because of the rural and forest scenes carved on its surface. Keats also goes on to say that music which is imagined is much sweeter than music which is actually heard.

Ah happy, happy boughs! That cannot shed

leaves, nor ever bid the spring adieu;

And, happy melodist, unwearied,

Forever piping songs forever new; 
More happy love! more happy, happy love!

Forever warm and still to be enjoyed,

Forever painting ,and forever young; (21-27)

Keats presented the artistic beauty of nature through his poems which can also enlighten humanity. This work of art has created immortal figures. Nature in any form like art will bring happiness to the world.

\section{WILLIAM WORDS WORTH:}

William Words worth well known as "priest of Nature". William Words worth drew attention of the readers toward rills and hills, skies and stars, rivers and trees. The beauty of nature. Modern life has made man to forget this beauty of nature. Urbanisation, globalisation, gradually swallow rural, natural beauty of the village which also sways mirth of men and women. He urges human beings to understand nature in order to get happiness. He personifies nature and natural objects in a most imaginative way. He feels sad about the gulf between nature and humanity. He is not only against the unhealthiest civilisation but also against the drop brutality of the machine world. William words worth depicts nature in" Daffodils"

"Besides the lake, beneath the tree

Fluttering and dancing in the bridge".

Words worth believes that "nature is a teacher whose wisdom we can learn, and without human is vain and incomplete".

Another poem words worth stress on how modern life is divorced from nature in Tintern Abbey. He writes:

Through a long absence, have not been to me

As is a landscape to a blind man's eye:

But oft, in lonely rooms,and'mid the din

Of towns and cities, that owned to them.

In hours of weariness, sensation sweat,(22-27)

Wordsworth expresses the power of remembrance of beautiful scenes to console amid weariness, to affect and humanise the life and to lift man above his bodily needs and perplexities of the concrete world.

"The anchor of my purest thoughts, the nurse

The guide, the guardian of my heart, soul (109-111)

Wordsworth moralise nature; he acknowledge Nature as his great Guru. He treats nature as a friend, guide and guardian.

Knowing that nature never did betray

the heart that loved her; tis is her privilege,

Through all the years of this our life, lead

from joy to joy...(122-125)

Wordsworth believes nature never betray her sister. This nature will bring happiness to his sister to lead a better life after his demise in the world. This hope is not only for his sister but also for entire mankind. William Words worth understand that nature has capacity to heal if a man treats her as a friend nature will cure all ailments of him. Nature works as a source of treatment to all the ailments of human beings.

\section{PERCY BYSSHE SHELLEY:}

Percy Bysshe Shelley is a lover of nature. Love for nature is one of the key-notes of his poetry. His poetry abounds in Nature imagery. Shelley believes that Nature exercises a healing influence on man's personality. He finds solace and comfort in nature and feels soothing influence on his heart. He treats poetry as a tool for pouring his thoughts to the world. He presents the changing and indefinite moods of Nature e.g. clouds, wind, lightening, rocks and caves the fury of the storms, waves dancing fast and bright etc.Shelley makes a request to the west wind to make humans beings happy.In his Ode to the West Wind, He appeals:

Drive my dead thoughts over the universe,

Like withered leaves to quicken a new birth!(63-64)

He appeals to the west wind, the most forceful agent in nature to drive away his dead thoughts (old memories) from him like shrunken leaves in order to start a new life ,the life of happiness. These words are not only for Shelley to remain happy but for all men and women in the world to be happy.

Another poem of Shelley To a Skylark. he describes skylark as a "blithe Spirit "rather than a bird, for its songs comes from Heaven, and from its full heart pours "profuse strains of unpremeditated art". He brings the attention of bird and teaches us to enjoy natural attitude of it. Skylark sings like a poet hidden in the glow of his thoughts and influencing the whole world. He says no song that man sings can ever match the raptures of the birds. Shelley urges human beings to get bliss with nature through this bird. He consider the Skylark the source of its happiness:

What objects are the fountains

Of thy happy strain? 
What fields, or waves, or mountains?

what shape of sky or pain(71-74)

Shelley accepts that natural (fountains, fields, waves, mountains etc) things are the source of happiness. He feels human beings are beyond the happiness of this bird. If they give up hate, pride, fear and sorrow they will reach the steeps of joy like Skylark. He writes:

Yet if we could scorn

Hate, and pride, and fear;

If we were things born

Not to shed a tear(86-89)

Shelley points out another fear of mankind are fear of death which is completely ignored by by the bird while flying high on the sky. The bird rises higher and higher from the earth a continues singing as it soars up. This poem teaches that man should not have fear of death and do enjoy the present moment like the Skylark which goes higher and higher without any fear of death. Man should also have to enjoy the present movement.

\section{CONCLUSION}

William Words Worth, Percy Bysshe Shelley and John Keats are priest of nature, true lover of nature, lover and admirer of nature. They state nature has bestowed, unwearied joy to mankind. Nature works as source of inspirations. Nature woks as a source of generating happiness and is a best guide for human beings to live a happy life. William Wordsworth approaches nature as a power of beauty and balm for happy, peace and calm. It is to say where William Words Worth's imagination isolates and focuses and John Keats fills in and enriches, Percy Bysshe Shelley's dissolves and transcends. These three romantic poets have tried their best to bring happiness to humanity and shake all their sorrows through natural beauty and rural setting in their poems. They believed that nature has answer for all unanswered questions. They celebrate the beauty of nature in its various dimensions. To conclude nature is our best guide, source of inspiration to lead a happy and prosperous life.

\section{REFERENCES}

[1]. Emotions recollected, Prepared by Board of Experts.

[2]. Experience and emotions by Mohammad Aslam and A.H.Tak

[3]. History of English literature by J.N.Mundra,S.C.Mundra

[4]. Dr.A.Chandra Bose," Generating Happiness through Nature by Romantic poets", Research Journal of English Language and Literature (RJELAL), vol.1.Issue.3, 2013. 